\title{
An Evaluation of the Factors Affecting Exclusive Breastfeeding
}

\author{
Sadece Anne Sütü ile Beslemeye Etki Eden Faktörlerin Değerlendirilmesi
}

\author{
(1) Gamze Özgürhan'1 (1) Serdar Cömert² \\ 1istanbul Training and Research Hospital, Clinic of Pediatrics, İstanbul, Turkey \\ 2istanbul Training and Research Hospital, Clinic of Pediatrics, Division of Neonatology, i̇stanbul, Turkey
}

\begin{abstract}
Introduction: Breast milk is not only the ideal nourishment for babies, but is also unique in terms of its health benefits for mothers and economic benefits for the society. The World Health Organization and United Nations Children's Fund support exclusive breastfeeding for the first 6 months of post-natal life.

Methods: A total of 355 mothers who all delivered in our hospital were included in this study. A questionnaire was created to include questions regarding the mothers' opinions about breast milk and their reasons for continuing or discontinuing exclusive breastfeeding. We collected other data separately, including the socio-cultural and socio-economic characteristics of the mothers, fathers and babies. Using the data collected, the mothers were grouped and compared according to their breastfeeding behaviour. Fathers were also grouped according to their paternal characteristics and their potential impact on the mothers' breastfeeding behaviour was investigated.
\end{abstract}

Results: In this study, $49 \%$ of the mothers expressed the belief that breast milk is healthy and protects babies from diseases. of the mothers who discontinued exclusive breastfeeding, $44.3 \%$ did so because they thought their milk was insufficient for their babies. In addition, 56.5\% of mothers continued exclusive breastfeeding at post-natal month 4 and 35.2\% at month 6. A higher percentage of mothers with a high level of education continued exclusive breastfeeding $(p=0.011)$. There was no statistically significant difference between the different age groups in terms of breastfeeding behaviour. Mothers with healthy medical histories were found to have continued exclusive breastfeeding for longer periods than the others $(p=0.037)$. Mothers who had help at home also continued exclusive breastfeeding for longer periods $(p=0.031)$. Mothers using pacifiers were found to have a higher exclusive breastfeeding discontinuation rate than the others $(p=0.007)$.

Conclusion: The leading reasons for discontinuing breastfeeding are incorrect and inadequate information about breastfeeding. Therefore, it is imperative that mothers are supported with appropriate and consistent education, both before and after birth, regarding the benefits of continued breastfeeding.

Keywords: Exclusive breastfeeding, pacifier, mother's attitude, bottle feeding, mother milk

\section{ÖZ}

Amaç: Anne sütü, bebekler için eșsiz bir besin kaynağı olmasının yanı sıra anne sağlığı ve toplum ekonomisi için de önemlidir. Dünya Sağlık Örgütü ve Birleșmiş Milletler Çocuklara Yardım Fonu ilk 6 ay sadece anne sütüyle beslenmeyi desteklemektedir.

Yöntemler: Bu çalıșmaya hastanemizde doğum yapan 355 anne ve bebeği dahil edildi. Annelere uygulanan ankette; anne sütü hakkındaki düșünceleri, sadece anne sütüyle beslemeye devam etme ya da etmeme sebepleri soruldu. Anne, baba ve bebek için sosyo-kültürel ve sosyo-ekonomik özellikler dahil olmak üzere tüm sosyo-demografik veriler kaydedildi. Anneler emzirme davranıșlarına göre gruplandırıldı ve karșılaștırıldı. Babaların sosyo-demografik özelliklerinin annelerin emzirme davranışları üzerine etkileri araștırıldı.

Bulgular: Çalışmadaki annelerin \%49'u anne sütünün sağlıklı olduğuna ve bebekleri hastalıklardan koruduğuna inanıyordu. Emzirmeyi bırakan annelerin \%44,3'ü sütlerinin bebekleri için yetersiz olduğunu düşünüyordu. Annelerin $\% 56,5$ `i bebeklerini doğum sonrası ilk 4 ay sadece anne sütü ile beslerken, \%35,2'si ilk 6 ay sadece anne sütü ile beslediği görüldü. Emzirme davranıșı açısından farklı yaş grupları arasında istatistiksel olarak anlamlı bir fark bulunmadı. Yüksek eğitim düzeyine sahip anneler ve sağlıklı tıbbi öyküsü olan annelerin sadece anne sütü ile beslemeyi diğerlerinden daha uzun süre sürdürdüğü bulundu $(p=0,011),(p=0,037)$. Evde yardımcısı olan anneler daha uzun süre sadece anne sütü ile beslemeye devam ettiler ( $p=0,031)$. Emzik kullanan annelerin sadece anne sütü ile beslemeyi daha önce bıraktıkları bulundu $(p=0,007)$.

Sonuç: Emzirmeyi bırakmanın bașlıca nedenleri emzirme hakkında yanlış ve yetersiz bilgilerdir. Bu nedenle annelerin, emzirmeye devam etmenin yararları konusunda hem doğumdan önce hem de sonra uygun ve tutarlı bir eğitim ile desteklenmesi zorunludur.

Anahtar Kelimeler: Sadece anne sütü ile besleme, emzik, anne davranışı, biberon ile besleme, anne sütü
Address for Correspondence/Yazıșma Adresi: Gamze Özgürhan MD, İstanbul Training and Research Hospital, Clinic of Pediatrics, İstanbul, Turkey

Phone: +90 5327748948 E-mail: gamzeozgurhan@yahoo.com ORCID ID: orcid.org/0000-0002-8063-1931

Cite this article as/Atıf: Özgürhan G, Cömert S. An Evaluation of the Factors Affecting Exclusive Breastfeeding. İstanbul Med J 2020; 21(4): 301-6.
Received/Geliş Tarihi: 31.05 .2020 Accepted/Kabul Tarihi: 11.06 .2020

(C) Copyright 2020 by the University of Health Sciences Turkey, Istanbul Training and Research Hospital/istanbul Medical Journal published by Galenos Publishing House.

(C) Telif Hakkı 2020 Sağıı Bilimleri Üniversitesi Istanbul Ĕgitim ve Araştırma Hastanesi/Istanbul Tıp Dergisi, Galenos Yayınevi tarafından basılmıștır. 


\section{Introduction}

Breast milk is unique in that it provides the ideal nourishment for the growth babies and also for the development of their immune system. Its benefits are not limited to infant health, but also extend to maternal health as well as to economical saving for the society (1-4). For these reasons, many national and international institutions, including the World Health Organization (WHO) and United Nations Children's Fund (UNICEF) advocate for the need of exclusive breastfeeding during the first 6 months following birth and the continuation of breastfeeding with necessary supplements until the age of 2 years $(4,5)$.

Exclusive breastfeeding is defined as breastfeeding with breast milk only, without any other liquid supplements such as water or any solids (6). In many countries, most mothers start feeding their babies artificial supplements within the first 6 months of life and discontinue breastfeeding within the first 2 years. The most common reason for this behaviour is the mothers' conviction that breast milk is not sufficient for their babies or due to certain difficulties they face with breastfeeding, including not knowing how to continue breastfeeding while working outside of their homes. At other times, the reason may be as simple as that the mother does not have anyone to provide the support she needs or that the guidance and information received from health care professionals was not in support of breastfeeding (7-13).

Although breastfeeding is common in Turkey, exclusive breastfeeding dropped from $42 \%$ in 2008 to $30 \%$ in 2013, according to Turkey Population and Health Research (TPHR). This data suggests that exclusive breastfeeding is recommended, but is not widely practiced. It is common to encounter cases where babies are fed with formula or bottles. The percentage of babies receiving supplements within the first 6 months has increased from 8\% in 2008 to $12 \%$ in 2013. This ratio varies significantly across different cultures and societies (14).

The primary aim of this study was to examine the factors leading to mothers to discontinue exclusive breastfeeding within the first 6 months of life. We also assessed the reasons for continuing exclusive breastfeeding as well as opinions regarding breast milk.

\section{Methods}

This prospective and comparative study was conducted according to the principles of the Declaration of Helsinki and was approved by the Bağclar Training and Research Hospital Non-interventional Clinical Research Ethics Committee (protocol no:2016/446, date: 17.03.2016). All the participants received oral and written information about the study and each participant provided a written informed consent.

\section{Study Population and Design}

The study included babies born in same hospital and their mothers. This hospital is the only public maternity clinic in the area with an average of 4,500 births/year and has a patient population distribution similar to that of Turkey's. Three or four cases per day were randomly selected as subjects from among the new-borns, who were born between March and July 2016 and were at 38 to 42 gestational weeks. Exclusion criteria included preterm births ( $<38$ weeks) and unhealthy babies. All the new-borns received a comprehensive physical examination, including measuring the weight, height and head circumference (Table 1).
Data (age, type of delivery, parity, education, occupation, medical history, family type, consanguinity) was collected from the mothers via face-to-face post-natal interviews (within 3 days following delivery). Father's age, education and occupation, as well as monthly household income were also collected.

We also examined the mothers' opinions concerning breast milk and their reasons for discontinuing breastfeeding if they chose to do so. The methodology was as follows: after the mothers' opinions concerning breast milk were obtained (Table 2), they were informed about breast milk and its benefits by same specialist. At 2 weeks, 2 months, 4 months and 6 months after birth, the specialist called each mother and asked whether they have continued breastfeeding and if not, their reasons for discontinuation (Table 3). The specialist also asked whether any supplements (e.g. water, solids and formula) were given to the baby, if pacifiers/bottles were used and whether there was anyone helping the mother. Fifteen cases were excluded during follow-up because they were unreachable.

Exclusive breastfeeding is defined as breastfeeding with breast milk only, without any other liquid supplements (including water) or any solids for the first 6 months of life. Partial breastfeeding is defined as providing artificial nutrients to an infant in addition to breast milk. No breastfeeding is defined as complete cessation of breastfeeding before 6 months. The information gathered was classified according to the definitions above in Tables 4 and 5.

Mothers were classified according to their age, education, income level, medical history, occupation, consanguineous marriage, family type, helper at home, delivery method and use of pacifier (Table 5). These groups of mothers were then compared according to their exclusive breastfeeding behaviour.

\section{Statistical Analysis}

All statistical analyses were performed using the Statistical Package for Social Sciences (SPSS) version 20.0 for Windows (SPSS, Chicago, IL). The 1-sample Kolmogorov-Smirnov test was used to evaluate the distribution characteristics of the variables. Demographic and clinical characteristics of the Exclusive Breastfeeding and Discontinuing Exclusive Breastfeeding groups were compared using the Mann-Whitney $U$ test for continuous variables and the $\chi^{2}$ test for categorical variables. Logistic regression model was used for multivariate analysis. A $p<0.05$ was considered statistically significant.

\section{Results}

This study included 355 mothers and their babies. The mothers' breastfeeding behaviour and factors affecting this behaviour were tracked for the first 6 months of post-natal life. The demographic and clinical characteristics of the mothers and their babies are shown in Table 1.

We asked their opinions about breast milk and the mothers mentioned the following three beliefs the most: $49 \%$ of the mothers think breast milk is healthy and protects infants from diseases, $41.1 \%$ find it more nutritious than other options and $31.6 \%$ consider it the most natural food for their babies. Other opinions can be found in Table 2 . 
Three hundred and fifty participants (98.6\% of the total participants) started breastfeeding after birth, while five participants (1.4\%) did not breastfeed at all. After the first post-natal month, one third of the mothers had stopped exclusive breastfeeding (31.6\%, shown in Table 4). The percentage of mothers continuing exclusive breastfeeding from month 1 to month 4 was found to be quite high (month 1, 68.4\%; month $4,56.5 \%)$. In addition, $42 \%$ of the participants who continued breastfeeding after the fourth month started including supplements in their babies' diets. The percentage of mothers who were breastfeeding exclusively by month 4 was $56.5 \%$ and $35.2 \%$ by month 6 . Twenty-six participants (7.3\%) fed their babies with breast milk and water within the first 6 months.

The most common three reasons given by the mothers for discontinuing exclusive breastfeeding were as follows: $44.3 \%$ said they were concerned that their milk was not sufficient for their babies, $19.1 \%$ reported that it was because their babies were not gaining weight and 13.9\% mentioned that their babies did not want to breastfeed. The remaining reasons can be found in Table 3.

We found that the percentage of mothers who continued exclusive breastfeeding was significantly higher among mothers with a high level of education $(p=0.011$ ). Regarding breastfeeding behaviour, there was no statistically significant difference between the different age groups. Mothers with a certain medical condition reported discontinuing exclusive breastfeeding sooner $(p=0.037)$ than healthy mothers. Mothers who had someone helping them at home with their baby continued exclusive breastfeeding longer than the others $(p=0.031)$. Mothers using pacifiers were observed to have transitioned to adding supplements

\begin{tabular}{|c|c|}
\hline \multicolumn{2}{|l|}{ Baby } \\
\hline Gender (male/female) (n) & $175 / 180$ \\
\hline Height $(\mathrm{cm})($ mean \pm SD) & $50.1 \pm 1.2$ \\
\hline Weight (g) (mean \pm SD) & $3201.4 \pm 469.2$ \\
\hline Head circumference $(\mathrm{cm})($ mean $\pm \mathrm{SD})$ & $34.9 \pm 0.8$ \\
\hline \multicolumn{2}{|l|}{ Mother } \\
\hline Age (years) (mean \pm SD) & $28.3 \pm 5.2$ \\
\hline \multicolumn{2}{|l|}{ Delivery method } \\
\hline Vaginal/caesarean section (n) & $179 / 176$ \\
\hline
\end{tabular}

\section{Table 2. Mothers' opinions about breastfeeding}

\begin{tabular}{l|l|}
\hline Opinions* & (n) \% \\
\hline It is healthier and protects against diseases & $(174) 49.0$ \\
\hline More nutritious & $(146) 41.1$ \\
\hline The most natural food & (112) 31.6 \\
\hline Affordable and hassle-free to give & (42) 11.9 \\
\hline To develop a close relationship with my baby & (21) 5.9 \\
\hline Doctor says it is better & (14) 4.0 \\
\hline Other opinions & (35) 9.9 \\
\hline *Mothers may have given more than one opinion on breastfeeding & \\
\hline
\end{tabular}

to their babies' diets and to have discontinued exclusive breastfeeding sooner compared to the mothers who do not use pacifiers $(p=0.007)$. Other maternal socio-cultural and socio-economic characteristics are shown in Table 5.

In the logistic regression analysis, the presence of a helper for the mothers at home and pacifier use were found to be a factor independently affecting exclusive breastfeeding (Table 6).

Regarding paternal characteristics, there were no statistically significant differences in terms of age, education or occupation.

\section{Discussion}

Although health authorities strongly recommend exclusive breastfeeding, this advice has not been put into practice at a satisfactory level. This is the main reason why mothers' breastfeeding behaviour is supported by health policies and various educational programmes by health personnel globally (15). In our study, we found that exclusive breastfeeding occurred with $35.2 \%$ of participants. Although this percentage is higher than the country average of 30\% (TPHR 2013) (14), we have a long way to go before we hit the 2025 target set by WHO and UNICEF in Global Nutrition Targets 2025: >50\% exclusive breastfeeding in the first 6 months (15). In a study examining breastfeeding with and

\section{Table 3. Reasons for discontinuing exclusive breastfeeding}

\begin{tabular}{l|l}
\hline Reasons* & (n) $\%$ \\
\hline I am concerned that my milk is not sufficient for my baby & (157) 44.3 \\
\hline My baby is not gaining weight & (68) 19.1 \\
\hline My baby does not want breast milk & (49) 13.9 \\
\hline My baby's health has deteriorated & (46) 13.0 \\
\hline I wanted my baby to taste something else as well & (34) 9.6 \\
\hline My baby is restless and crying and I think he/she is not satisfied & (15) 4.3 \\
\hline $\begin{array}{l}\text { Breast-related problems (mastitis, engorgement, cracked or sore } \\
\text { nipple) }\end{array}$ & (12) 3.5 \\
\hline I was affected by the people around me & (9) 2.6 \\
\hline Breastfeeding contra-indicated & (9) 2.6 \\
\hline Other reasons & (9) 2.6
\end{tabular}

*Mothers who may have given more than one reason for discontinuing

Table 4. Rates of no, partial and exclusive breastfeeding from 1 to 6 month

\begin{tabular}{|c|c|c|c|}
\hline $\begin{array}{l}\text { Age } \\
\text { (Month) }\end{array}$ & $\begin{array}{l}\text { No } \\
\text { Breastfeeding* } \\
\text { (n) } \%\end{array}$ & $\begin{array}{l}\text { Partial } \\
\text { Breastfeeding** } \\
\text { (n) } \%\end{array}$ & $\begin{array}{l}\text { Exclusive } \\
\text { Breastfeeding***} \\
\text { (n) } \%\end{array}$ \\
\hline 1 & (16) 4.5 & (96) 27.1 & (243) 68.4 \\
\hline 2 & (26) 7.3 & (103) 28.9 & (226) 63.8 \\
\hline 3 & (34) 9.6 & (106) 29.9 & (215) 60.5 \\
\hline 4 & (42) 11.9 & (112) 31.6 & 56.5 \\
\hline 5 & (50) 14.1 & (148) 41.8 & (157) 44.1 \\
\hline 6 & (56) 15.8 & (174) 49.0 & (125) 35.2 \\
\hline \multicolumn{4}{|c|}{$\begin{array}{l}\text { *Complete cessation of breastfeeding } \\
* * \text { Providing artificial nutrients to an infant in addition to breast milk } \\
* * * \text { Breastfeeding with breast milk only, without any other liquid supplements (including } \\
\text { water) or any solids }\end{array}$} \\
\hline
\end{tabular}


without prenatal breast milk and breastfeeding training, the rates of exclusive breastfeeding at month 6 were $67.8 \%$ and 28\%, respectively (16). In another national study, exclusive breastfeeding rate was $45 \%$ at month 4 (17). The importance of breastfeeding has been more widely acknowledged in low and middle-income countries; however, breastfeeding in high-income countries has been on the decline (18). Between 2006 and 2012, exclusive breastfeeding was at 25\% in the WHO European Region, while it was at $43 \%$ in the WHO South-East Asia

\begin{tabular}{|c|c|c|c|}
\hline Characteristics & $\begin{array}{l}\text { Discontinuing } \\
\text { Exclusive } \\
\text { Breastfeeding } \\
(n=230) \%\end{array}$ & $\begin{array}{l}\text { Exclusive } \\
\text { Breastfeeding } \\
(n=125) \%\end{array}$ & $\mathbf{p}$ \\
\hline \multicolumn{4}{|l|}{ Age at delivery (Years) } \\
\hline$<25$ & (62) 26.9 & (36) 28.8 & \multirow{4}{*}{ ns } \\
\hline $25-29$ & (71) 30.9 & (41) 32.8 & \\
\hline $30-34$ & (67) 29.1 & (35) 28.0 & \\
\hline$>34$ & (30) 13.1 & (13) 10.4 & \\
\hline \multicolumn{4}{|l|}{ Education } \\
\hline Illiterate & (19) 8.3 & (7) 5.6 & \multirow{5}{*}{0.011} \\
\hline Primary school & (101) 43.9 & (33) 26.4 & \\
\hline Secondary school & (79) 34.3 & (41) 32.8 & \\
\hline High school & (23) 10.0 & (29) 23.2 & \\
\hline University & (8) 3.5 & (15) 12.0 & \\
\hline \multicolumn{4}{|c|}{ Monthly income (Turkish Liras) } \\
\hline$<1500$ & (160) 69.6 & (88) 70.4 & \multirow{3}{*}{ ns } \\
\hline $1500-3000$ & (59) 25.6 & (28) 22.4 & \\
\hline$>3000$ & (11) 4.8 & (9) 7.2 & \\
\hline Disease presence & (29) 12.6 & (7) 5.6 & 0.037 \\
\hline Occupation & (35) 15.2 & (22) 17.6 & ns \\
\hline Consanguineous marriage & (41) 17.8 & (25) 20.0 & ns \\
\hline \multicolumn{4}{|l|}{ Family type } \\
\hline Small* & (177) 76.9 & (91) 72.8 & \multirow{2}{*}{ ns } \\
\hline Large & (53) 23.1 & (34) 27.2 & \\
\hline Helper at home & (35) 15.2 & (29) 23.2 & 0.031 \\
\hline \multicolumn{4}{|l|}{ Delivery method } \\
\hline Vaginal & (114) 49.6 & (65) 52.0 & \multirow{2}{*}{ ns } \\
\hline Caesarean section & (116) 50.4 & (60) 48.0 & \\
\hline Pacifier use (First 1 month) & (104) 45.2 & (24) 19.2 & 0.007 \\
\hline
\end{tabular}

\begin{tabular}{|c|c|c|c|c|}
\hline & $\beta$ & p & OR & $95 \% \mathrm{Cl}$ \\
\hline Maternal education & -0.12 & 0.158 & 0.20 & $0.52-1.52$ \\
\hline Maternal illness & -0.56 & 0.27 & 1.21 & $0.21-1.55$ \\
\hline Helper at home & 0.62 & 0.035 & 4.44 & $0.30-0.96$ \\
\hline Pacifier use & 0.23 & 0.03 & 1.61 & $0.64-1.41$ \\
\hline
\end{tabular}

$\beta$ : Beta coefficient, OR: odds ratio, $\mathrm{Cl}$ : confidence interval
Region. More recent data (2015) from 21 countries in Europe show that exclusive breastfeeding has now dropped to $13 \%(19)$.

The benefits of breast milk are widely known by mothers and this awareness has been the main driving factor behind breastfeeding (20). In our study, mothers predominantly believed that breast milk is healthier, protects against disease and that it is more nutritious. This by itself indicates that most of the mothers understand the importance of breast milk. However, other factors often have a negative impact on the inclination to breastfeed. The mothers' empirical decisions and values have been shown to inhibit breastfeeding (21). Mothers who are less confident about breast milk discontinue breastfeeding at earlier stages (22). In our study, the main reasons for discontinuing breastfeeding were concerns that the breast milk is not sufficient for the baby and that the baby was not gaining weight. To mitigate these concerns, education and support for breastfeeding for mothers, as well as continuous and sufficient information flow to mothers during followups would boost the mothers' confidence and have a positive impact on their breastfeeding behaviour (23).

Many studies showed that maternal age and level of education has a strong positive correlation with breastfeeding in developed countries (24-26). However, in developing countries, there is an inverse correlation as we see other factors such as traditional breastfeeding behaviours and advice from family and friends becomes more dominant (27). As the age and level of education of the mother increases, so does the percentage of mothers who start and continue to breastfeed. The older the mother, the more likely she is to start and continue breastfeeding $(24,28,29)$. Very young mothers are more likely to have lower education and a higher tendency to feed their babies formula (30). In another study, first-time mothers were found to be more likely to continue breastfeeding (31). In our study, exclusive breastfeeding was more common in mothers with high levels of education; however, there was no statistically significant difference in breastfeeding behaviour among different age groups.

Less educated and younger mothers are less likely to use alternatives to pacifiers to calm their babies and are more likely to introduce pacifiers to their babies at earlier stages. This leads to discontinuation of the exclusive breastfeeding (32). In our study, we observed that mothers who introduced pacifiers to their babies within the first month are less likely than the other mothers to continue exclusive breastfeeding.

Another major factor associated with breastfeeding is the mother's socioeconomic status (occupation, household income, etc). In developed countries, there is a positive correlation between high income and breastfeeding (26-28); however, there is an inverse correlation in developing countries (29). In our study, there was no statistically significant relationship between household income/mother's occupation and breastfeeding continuation. In addition, having a helper at home is positively correlated with breastfeeding according to our findings.

Another factor influencing the breastfeeding behaviour is the health of the mother. We found that mothers with any health condition are less likely to continue exclusive breastfeeding (33-35). Also, the method of infant delivery may have an impact on breastfeeding behaviour. Pain/discomfort after a caesarean may delay breastfeeding, whereas breastfeeding can commence sooner after vaginal birth (36). In our 
study, we did not come across any correlation between method of delivery and breastfeeding behaviours.

In November 2019, TPHR announced that exclusive breastfeeding as $40.7 \%$ in the first 6 months. The rate of breast-milk use decreased from $66 \%$ for one year to $34 \%$ for 2 years. The rate of feeding babies with other milk instead of breast milk is $23 \%$. Feeding with bottle is reported as $53 \%$ in the first 2 years (37).

Our study is important because it provides some valuable results on the breastfeeding behaviours of mothers; however, it has a few limitations. The first limitation is the small sample size. Secondly, we only followed-up the participants for 6 months after birth, as we focused on exclusive breastfeeding.

\section{Conclusion}

Breast milk is the best source of nutrition during the first 6 months of life. Therefore, it is an important public health objective to increase the number of mothers who practice exclusive breastfeeding. Hospital policies and practices are essential in meeting this objective. Within the scope of the Baby-Friendly Hospital Initiative, the confidence of the mothers needs to be boosted through education about breast milk and breast feeding both in the prenatal and post-natal periods. In addition, a high level of awareness regarding the benefits of breastfeeding needs to be created among health care personnel and in the society, with education supported by factual and scientific information.

\section{Ethics}

Ethics Committee Approval: This prospective and comparative study was approved by the Bağcllar Training and Research Hospital Noninterventional Clinical Research Ethics Committee (protocol no: 2016/446, date: 17.03.2016).

Informed Consent: All the participants provided a written informed consent.

Peer-review: Externally peer-reviewed.

Authorship Contributions: Surgical and Medical Practices - G.Ö.; Concept - G.Ö., S.C.; Design - G.Ö., S.C.; Data Collection or Processing G.Ö.; Analysis or Interpretation - G.Ö., S.C.; Literature Search - G.Ö., S.C.; Writing - G.Ö.

Conflict of Interest: No conflict of interest was declared by the authors.

Financial Disclosure: The authors declared that this study received no financial support.

\section{References}

1. Gartner LM, Morton J, Lawrence RA, Naylor AJ, O'Hare D, Schanler RJ, et al. Breastfeeding and the use of human milk. Pediatrics 2005; 115: 496-506.

2. Kramer MS, Kakuma R. The optimal duration of exclusive breastfeeding: a systematic review. Adv Exp Med Biol 2004; 554: 63-77.

3. Gartner LM, Morton J, Lawrence RA, Naylor AJ, O'Hare D, Schanler RJ, et al. Breastfeeding and the use of human milk. Pediatrics 2005; 115: 496-506.

4. World Health Organization. Breastfeeding. Available from URL: http://www. who.int/topics/breastfeeding/en/ (accessed 14th August, 2010)
5. WHO/UNICEF. Global strategy for infant and young child feeding; World Health Organization: Geneva, Switzerland, 2003.

6. WHO. Indicators for assessing infant and young child feeding practices (Part 1) Definitions. 2008 (http://whqlibdoc.who.int/ publications/2008/9789241596664_eng.pdf) (accessed 1/08/2009)

7. Essex C, Smale P, Geddis D. Breastfeeding rates in New Zealand in the first 6 months and the reasons for stopping. N Z Med J 1995; 108: 355-7.

8. Vogel A, Hutchison BL, Mitchell EA. Factors associated with the duration of breastfeeding. Acta Paediatr 1999; 88: 1320-6.

9. Avery M, Duckett L, Dodgson J, Savik K, Henly SJ. Factors associated with very early weaning among primiparas intending to breastfeed. Matern Child Health J 1998; 2:167-179.

10. Deshpande AD, Gazmararian JA. Breast-feeding education and support: association with the decision to breast-feed. Eff Clin Pract 2000; 3: 116-22.

11. Ertem IO, Votto N, Leventhal JM. The timing and predictors of the early termination of breastfeeding. Pediatrics 2001; 107: 543-8.

12. Losch M, Dungy CI, Russell D, Dusdieker LB. Impact of attitudes on maternal decisions regarding infant feeding. J Pediatr 1995; 126: 507-14.

13. Scott JA, Binns CW. Factors associated with the initiation and duration of breastfeeding: a review of the literature. Breastfeed Rev 1999; 7: 5-16.

14. Turkey Demographic and Health Survey. 2013 Report. Available from URL: www.hips.hacettepe.edu.tr/tnsa2013/rapor/TNSA_2013_ana_rapor.pdf

15. World Health Organization, UNICEF. Global Nutrition Targets 2025: Breastfeeding policy brief. 2014 Available from URL: http://www.who.int/ nutrition/publications/globaltargets2025_policybrief_breastfeeding/en/

16. Onbaşı Ş, Duran R, Çiftdemir NA, Vatansever Ü, Acunaș B, Süt N. The effect of prenatal breast-milk and breast-feeding training given to expectant mothers on the behaviour of breast-feeding. Turk Arch Ped 2011; 46: 74-8.

17. Kondolot M, Yalçın SS, Yurdakök K. Sadece anne sütü alım durumuna etki eden faktörler. Çocuk Sağlığı ve Hastalıkları Dergisi 2009; 52:122-7.

18. Breastfeeding in the 21st century: epidemiology, mechanisms, and lifelong effect. Lancet 2016; 387: 475-90.

19. Regional Office for Europe of WHO. WHO European Region has lowest global breastfeeding rates. Available from: URL: https://www.euro.who.int/ en/health-topics/disease-prevention/nutrition/news/news/2015/08/whoeuropean-region-has-lowest-global-breastfeeding-rates (August-5-2015)

20. The National Information Centre, IFF Research. Infant feeding survey report 2010: Early results. 2011 Available from: URL: http://www.ic.nhs.uk/webfiles/ publications/003_Health_Lifestyles/IFS_2010_early_results/IFS_2010_ headline_report_tables2.pdf (accessed 16/09/2011)

21. Haku M, Ohashi K. Pursuit of factors limiting breastfeeding continuation, using Orem's dependent care model. Journal of Japan Academy of Midwifery 2004; 18: 6-18

22. Blyth R, Creedy DK, Dennis CL, Moyle W, Pratt J, De Vries SM. Effect of materna confidence on breastfeeding duration: an application of breastfeeding selfefficacy theory. Birth 2002; 29: 278-84.

23. Labarere J, Gelbert-Baudino N, Ayral AS, Duc C, Berchotteau M, Bouchon N, et al. Efficacy of breastfeeding support provided by trained clinicians during an early, routine, preventive visit: a prospective, randomized, open trial of 226 mother-infant pairs. Pediatrics 2005; 115: 139-46.

24. Dennis CL. Breastfeeding initiation and duration: A 1990-2000 literature review. J Obstet Gynaecol Neonatal Nurs 2002; 31: 12-32.

25. Scott JA, Landers MC, Hughes RM, Binns CW. Factors associated with breastfeeding at discharge and duration of breastfeeding. J Pediatr Child Health 2001; 37: 254-61. 
26. Waldenström U, Aarts C. Duration of breastfeeding and breastfeeding problems in relation to length of postpartum stay: a longitudinal cohort study of a national Swedish sample. Acta Pediatr 2004; 93: 669-76.

27. Forman MR. Review of research on the factors associated with choice and duration of infant feeding in less-develop countries. Pediatrics 1984; 74: 66794.

28. Haku M. Breastfeeding: factors associated with the continuation of breastfeeding, the current situation in Japan, and recommendations for further research. J Med Invest 2007; 54: 224-34.

29. Hoddinott P, Tappin D, Wright C. Breastfeeding. BMJ 2008; 336: 881-7.

30. Dubois L, Girard M. Social inequalities in infant feeding during the first year of life: The longitudinal study of child development in Quebec 1998-2002. Public Health Nutr 2003; 6: 773-83.

31. Bolling K, Grant C, Hamyln B, Thornton A. Infant feeding survey report 2005. The Information Centre, 2007. Available from URL: http://data.parliament. uk/DepositedPapers/Files/DEP2008-0853/DEP2008-0853.pdf (accessed 4/08/ 2010)
32. Mauch CE, Scott JA, Magarey AM, Daniels LA. Predictors of and reasons for pacifier use in first-time mothers: an observational study. BMC pediatr 2012; 12: 7.

33. Rioux FM, Savoie N, Allard J. Is there a link between postpartum anaemia and discontinuation of breastfeeding. Can J Diet Pract Res 2006; 67: 72-6.

34. Dunn S, Davies B, McCleary L, Edwards N, Gaboury I. The relationship between vulnerability factors and breastfeeding outcome. J Obstet Gynecol Neonatal Nurs 2006; 35: 87-97.

35. Galler JR, Harrison RH, Ramsey F, Chawla S, Taylor J. Postpartum feeding attitudes, maternal depression and breastfeeding in Barbados. Infant Behav Dev 2006; 26: 189-203.

36. Rondó PH, Souza MR. Maternal distress and intended breastfeeding duration. J Psychosom Obstet Gynaecol 2007; 28: 55-60.

37. Turkey Demographic and Health Survey. 2018 Report. Available from URL: http://www.hips.hacettepe.edu.tr/tnsa2018/rapor/TNSA2018_ana_Rapor.pdf 